\section{Rancangan Proses Koagulasi Model Pipa Melingkar pada Pengolahan Air}

\section{Sulaiman Hamzani}

Politeknik Kesehatan Kemenkes Banjarmasin Jurusan Kesehatan Lingkungan dengan bidang keahlian rekayasa pengolahan air dan limbah cair

$\bowtie \quad$ shamzenviro@gmail.com
Proses koagulasi disebut juga sebagai kondisi pengadukan cepat untuk menyebarkan bahan kimia seperti tawas dan kapur yang akan mengikatkan partikel koloid dalam air, sehingga terbentuk flok dan mudah mengendap. Penggunaan pipa fleksibel selang plastik yang dibuat melingkar disebut pipa circular digunakan sebagai alternatif. Intensitas atau gradien kecepatan (G) dan waktu pengadukan $(\mathrm{td}=\mathrm{V} / \mathrm{Q})$ sangat diperlukan dalam rancangan ini. Kriteria desain yang lebih penting adalah jumlah tumbukan antara 104-10 ${ }^{5}$ dan tidak stagnan (Gtd). Hasil perhitungan rancangan proses koagulasi model pipa melingkar dengan debit pengolahan air (Q) o,ooo5 $\mathrm{m}^{3} /$ detik, waktu kontak (td) 20 detik, Gtd 104, G teoritis 500 detik $^{-1}$, diameter selang (Ds) $\mathbf{1}^{\prime \prime}(0,032 \mathrm{~m})$, diameter lingkar selang (Dc) o,3 m diperoleh hasil sebagai berikut: panjang selang yang diperlukan (Ls) $12,4 \mathrm{~m}$, kecepatan aliran (Va) o,62 m/detik, angka Reynold (NRe) 23528 (sesuai kriteria: >400o turbulen), jumlah selang melingkar 14 buah, G hitung 506 detik $^{-1}$ (sesuai kriteria: 100-100o detik $^{-1}$ ). Rancangan ini dapat diterapkan pada proses flokulasi dan menghemat tempat.

Kata kunci : koagulasi, pipa melingkar, pengolahan air

Dlpresentasikan: 30 Agustus 2019

Direvisi: 14 September 2019

Diterima: 2 Oktober 2019

Dipublikasikan online: 5 Oktober 2019

\section{Pendahuluan}

Koagulasi sebagai pengadukan cepat merupakan proses terjadinya tumbukan atau destabilisasi muatan koloid tersuspensi dengan bahan koagulan membentuk flok-flok halus hingga dapat diendapkan. Selain itu kekeruhan, $\mathrm{pH}$ air, dan dosis koagulan akan berpengaruh terhadap koagulasi (Rachmawati dkk., 2009). Tujuan pengadukan cepat adalah untuk mempercepat penyebaran bahan koagulan terhadap air yang diolah, dimana proses hidrolis dalam hitungan detik dan terjadi adsorpsi partikel koloid. Proses penggumpalan flok tergantung dari waktu dan proses pengadukan dalam air olahan. Kecepatan aliran untuk pengolahan berkisar antara 0,45-0,9 m/detik (Joko, 2010).

Pengadukan hidrolis memanfaatkan gerakan air sebagai energi pengaduk seperti energi gesek media butiran, energi jatuhan atau ada lompatan hidrolis dalam aliran (Masduqi dan Slamet, 2002). Aliran dalam pipa dipengaruhi oleh viskositas, kecepatan aliran, panjang dan diameter pipa, serta belokan pipa (Rachmat, 2011). Aliran yang mengalir dalam pipa terjadi dengan kecepatan yang tidak sama dan distribusi aliran turbulen tergantung angka $\mathrm{NRe}$, memerlukan intensitas atau gradien kecepatan (G), lama pengadukan $(\mathrm{td}=\mathrm{V} / \mathrm{Q})$, banyaknya tumbukan imajiner $10^{4}-10^{5}$ (Gtd) dan tidak ada zona stagnan. Jenis pengadukan cepat hidrolis yang digunakan berupa turbulent pipe flow mixer adalah proses pencampuran yang terjadi di dalam saluran pipa tertutup dengan waktu pengadukan optimum sebesar 1 menit (Hamzani, 2013).

\section{Metode}

Bahan yang digunakan untuk rancangan proses koagulasi berupa selang plastik fleksibel berukuran 1" (diameter $0,032 \mathrm{~m}$ ). Perhitungan rancangan pada pengolahan air diperlukan data pendukung berupa tingkat kebutuhan air pengguna atau menyesuaikan debit mesin pompa yang ada, maka ditetapkan (Q) sebesar $0,0005 \mathrm{~m}^{3} /$ detik sesuai perhitungan $Q$ mesin pompa. Rumus perhitungan sesuai kriteria desain dan keterangan simbol pada rumus diuraikan sebagai berikut (Hamzani, 2013):

$\mathrm{Q}=$ debit aliran ( $\mathrm{m}^{3} /$ detik)

$\mathrm{Td}=\mathrm{V} / \mathrm{Q}$, waktu kontak (detik)

$\mathrm{Gtd}=10^{4}-10^{5}$, banyaknya jumlah tumbukan

$\mathrm{G} \quad=100-1000$ detik $^{-1}$, gradien kecepatan (detik $\left.{ }^{-1}\right)$

$\mathrm{V} \quad=\mathrm{Q} . \mathrm{td}$, volume air $\left(\mathrm{m}^{3}\right)$

Ds = diameter selang $(\mathrm{m})$

Dc $=$ diameter lingkar selang $(\mathrm{m})$

$r \quad=$ jari-jari selang $(\mathrm{m})$

$\mathrm{Ls} \quad=$ panjang selang $(\mathrm{m})$

$\mathrm{Va}=$ kecepatan aliran ( $\mathrm{m} /$ detik)

$\mathrm{NRe}=$ bilangan Reynold

$\mathrm{f} \quad=$ faktor gesekan

$v \quad=\rho / \mu$, viskositas kinematik ( $\mathrm{m}^{2} /$ detik)

$\mathrm{P} \quad=$ daya yang diberikan $\left(\mathrm{kg} \mathrm{m}^{2} /\right.$ detik $\left.^{3}\right),(\mathrm{J} /$ detik)

$\mu \quad=$ viskositas absolut zat cair $(\mathrm{kg} / \mathrm{m} /$ detik)

Cara mensitasi artikel ini:

Hamzani, S (2019) Rancangan Proses Koagulasi Model Pipa Melingkar pada Pengolahan Air. [Edisi Khusus]. Buletin Profesi Insinyur 2(3): 108-115 


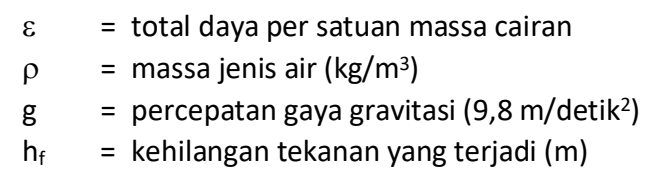

\section{Hasil Perhitungan}

Hasil perhitungan rancangan proses koagulasi model pipa melingkar diuraikan sebagai berikut:

1. Debit air olahan $(Q)=0,0005 \mathrm{~m}^{3} /$ detik

2. Waktu kontak (td) $=20$ detik (kriteria: $20-60$ detik)

3. Banyaknya tumbukan $(\mathrm{Gtd})=10.000$ (kriteria: 10.000-100.000)

4. Gradien Kecepatan $(\mathrm{G})_{\text {teoritis }}=\frac{10.000}{20 \text { detik }}=500$ detik $^{-1}$ (kriteria: 100-1000 detik $^{-1}$ )

5. Volume air $(V)=Q \times t d=0,0005 \times 20=0,01 \mathrm{~m}^{3}$

6. Diameter selang $1^{\prime \prime}(D s)=0,032 \mathrm{~m}$

7. Diameter lingkar selang $\left(D_{c}\right)=0,3 \mathrm{~m}$

8. Jari-jari selang $1^{\prime \prime}(r)=0,016 \mathrm{~m}$

9. Panjang selang $(\mathrm{Ls})=\frac{V}{\pi r^{2}}=\frac{0,01}{3,14 \times(0,016)^{2}}=12,4 \mathrm{~m}$

10. Kecepatan aliran $\left(\mathrm{V}_{\mathrm{a}}\right)=\frac{Q}{A}=\frac{Q}{\left(\frac{\pi \cdot d^{2}}{4}\right)}=\frac{0,0005}{\left[\frac{3,14 \times(0,032)^{2}}{4}\right]}=$ $0,62 \mathrm{~m} /$ detik

11. Angka Reynold (NRe) $=\frac{D s \cdot V a}{v}=\frac{0,032 \times 0,62}{8,46 \times 10^{-7}}=23528$ (kriteria: aliran turbulen $>4000$ )

12. Faktor Gesekan $(\mathrm{f})=\lambda=\frac{20}{N R e^{0,65}}\left(\frac{D s}{D_{c}}\right)^{0,175}=$ $\frac{20}{2352^{0,65}}\left(\frac{0,032}{0,3}\right)^{0,175}=0,019$

13. Headloss $\left(\mathrm{H}_{\mathrm{f}}\right)$ Mayor $=\Delta H=\lambda \cdot \frac{v_{a}^{2}}{2 g} \cdot \frac{L s}{D}=$ $0,019 \times\left[\frac{(0,62)^{2}}{2 \times 9,8}\right] \times \frac{12,4}{0,032}=0,15 \mathrm{~m}$
14. Keliling Lingkar Selang $=\pi \cdot D_{c}=3,14 \times 0,3=0,9 \mathrm{~m}$

15. Jumlah Selang Melingkar $=\frac{\text { Panjang Selang }}{\text { Keliling Lingkar Selang }}$ $=\frac{12,4}{0,9}=13,8 \approx 14 \mathrm{bh}$

16. Koefisien Elbow $90^{\circ}(\mathrm{K})=0,25$ kriteria: $0,15-0,25$ $\rightarrow$ long radius (flanged)

17. $(\mathrm{K})$ Total $=(\mathrm{K}) \mathrm{x}$ elbow lingkar selang $\mathrm{x}$ selang melingkar $=0,25 \times 4 \times 14=14$

18. Headloss $\left(\mathrm{H}_{\mathrm{f}}\right)$ Minor $=K \cdot \frac{v_{a}{ }^{2}}{2 g}=14 x\left[\frac{(0,62)^{2}}{2 \times 9,8}\right]=0,27 \mathrm{~m}$

19. Headloss $(\mathrm{H})$ Total $=\left(\mathrm{H}_{\mathrm{f}}\right)_{\text {Mayor }}+\left(\mathrm{H}_{\mathrm{f}}\right)_{\text {Minor }}$ $=0,15+0,27=0,42 \mathrm{~m}$

20. $\mathrm{G}_{\text {hitung }}=\left[\left(\frac{\text { h.p.g.Q }}{\mu . V}\right)\right]^{1 / 2}=\left[\left(\frac{0,42 \times 996 \times 9,8 \times 0,0005}{\left(0,8 \times 10^{-3}\right) \times 0,01}\right)\right]^{1 / 2}$

$=506$ detik $^{-1} \approx 500$ detik $^{-1}$

Koagulasi adalah proses fisika-kimia, dimana diperlukan energi dan waktu agar proses dapat berlangsung. Hasil perhitungan rancangan menunjukkan bahwa untuk waktu kontak (td) pada proses koagulasi model pipa melingkar dikondisikan selama 20 detik sesuai kriteria desain 20-60 detik. Sedangkan banyaknya tumbukan (Gtd) dikondisikan sebesar 10.000 sesuai kriteria desain $10^{4}-10^{5}$ menghasilkan $\mathrm{G}$ teoritis $=10.000 / 20$ detik $=500$ detik $^{-1}$ setara $\mathrm{G}$ hitung 506 detik $^{-1}$ memenuhi kriteria desain 100-1000 detik ${ }^{-1}$.

Pada pengadukan cepat harus terjadi aliran yang turbulen (destabilisasi) dengan kecepatan yang tidak sama dan distribusi tidak normal. Berdasarkan hasil perhitungan diperoleh angka Reynold (NRe) sebesar 23528 memenuhi kriteria aliran turbulen $>4000$. Rancangan proses koagulasi model pipa melingkar dapat dilihat pada Gambar 1 dan 2.

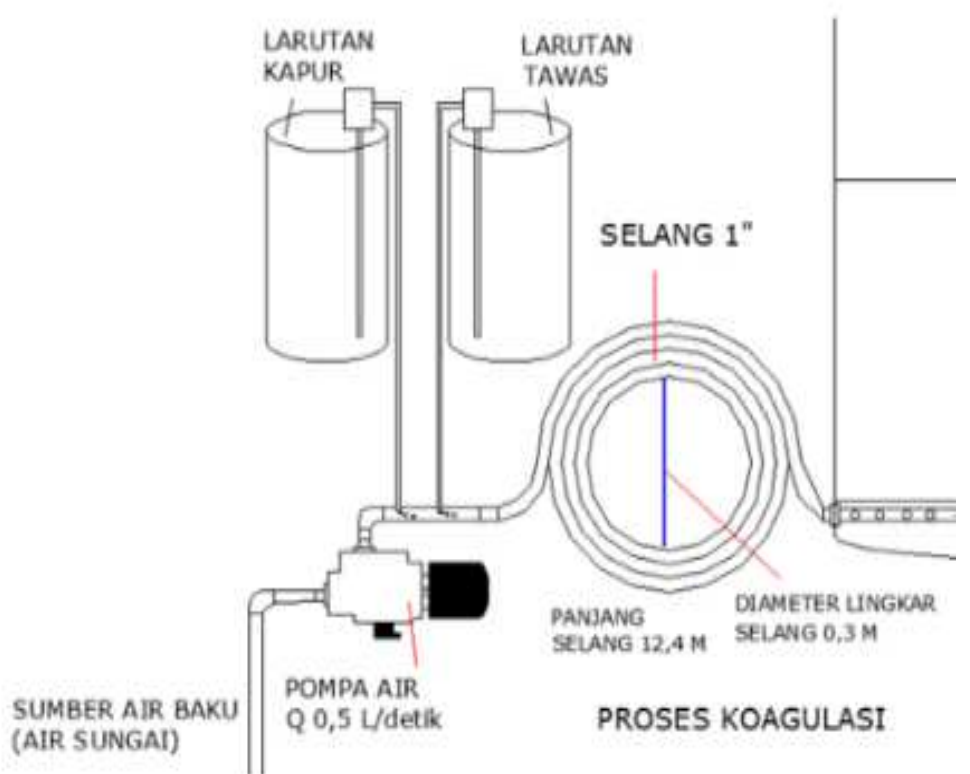

Gambar 1. Sketsa Proses Koagulasi Model Pipa Melingkar (Hamzani, 2013) 


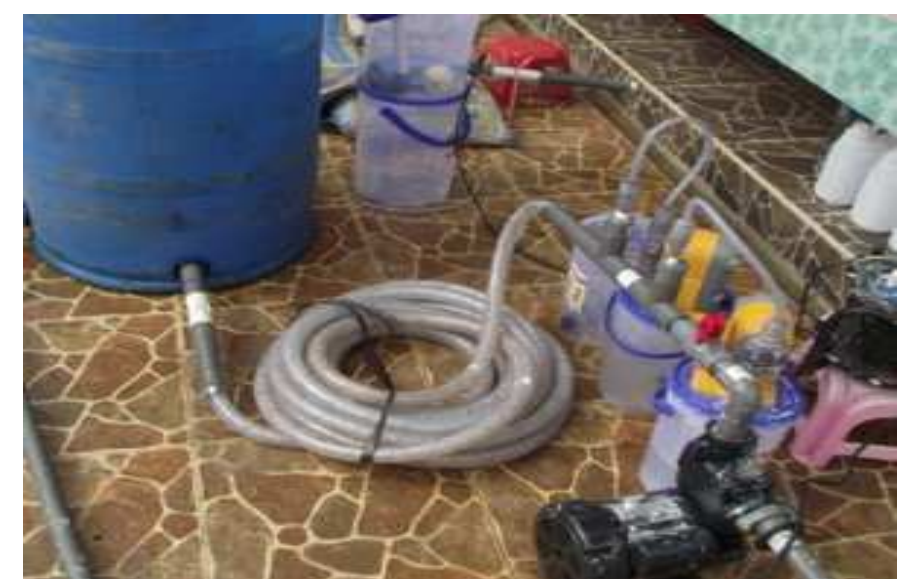

Gambar 2. Foto Proses Koagulasi Model Pipa Melingkar (Hamzani, 2013)

\section{Kesimpulan}

Dari hasil perhitungan diperoleh data sebagai berikut: panjang selang yang diperlukan (Ls) 12,4 meter, kecepatan aliran (Va) 0,62 meter/detik, angka Reynold (NRe) 23528 (sesuai kriteria: > 4000 turbulen), jumlah selang melingkar 14 buah, $\mathrm{G}$ hitung 506 detik $^{-1}$ (sesuai kriteria: $100-1000$ detik $^{-1}$ ). Rancangan ini dapat diterapkan pada flokulasi dan menghemat tempat.

\section{Ucapan Terimakasih}

Ucapan terimakasih kepada Politeknik Kesehatan Kemenkes Banjarmasin yang telah membiayai penelitian ini.

\section{Referensi}

Rachmawati, S.W., Iswanto, B., dan Winarni (2009), "Pengaruh pH pada Proses Koagulasi dengan Koagulan Aluminium Sulfat dan Ferri Klorida", Jurnal Teknologi Lingkungan, Vol. 5, No. 2, hal. 4045.

Joko, T. (2010), Unit Produksi dalam Sistem Penyediaan Air Minum, Perbit Graha Ilmu, Yogyakarta.

Masduqi, A. dan Slamet, A. (2002), Buku Ajar Satuan Operasi, Jurusan Teknik Lingkungan, FTSP-ITS, Surabaya.

Rachmat, F. (2011), Efek Panjang Pipa Terhadap Aliran Berkembang Penuh Untuk Air Tawar dan Larutan Biopolimer Cairan Beras Hasil Fermentasi, Tesis Teknik Mesin, Universitas Indonesia, Depok. 